\title{
Utilization of Water Quality Modeling and Dissolved Oxygen Control in River Tungabhadra, Karnataka (India)
}

\author{
S. Ranjith1 ${ }^{(1)}$, Anand V. Shivapur ${ }^{1}$, P. Shiva Keshava Kumar ${ }^{2}$, Chandrashekarayya G. Hiremath $^{3}$, \\ Santhosh Dhungana ${ }^{4}$
}

${ }^{1}$ VTU-PG Studies, Belagavi, India

${ }^{2}$ Department of Civil Engineering, PDIT Engineering College, Hosapete, Indian

${ }^{3}$ Department of Water and Land Management, VTU, Belagavi, India

${ }^{4}$ School of Environment, Resources and Development (SERD), Pathumthani, Thailand

Email: Ranjith.s009@gmail.com

How to cite this paper: Ranjith, S., Shivapur, A.V., Shiva Keshava Kumar, P., Hiremath, C.G. and Dhungana, S. (2019) Utilization of Water Quality Modeling and Dissolved Oxygen Control in River Tungabhadra, Karnataka (India). Open Access Library Journal, 6: e5397.

https://doi.org/10.4236/oalib.1105397

Received: April 1, 2019

Accepted: May 19, 2019

Published: May 22, 2019

Copyright $\odot 2019$ by author(s) and Open Access Library Inc.

This work is licensed under the Creative Commons Attribution International License (CC BY 4.0).

http://creativecommons.org/licenses/by/4.0/

\begin{abstract}
In an attempt to produce a reliable source of water, the water quality model-QUAL2Kw-was put to through calibration and validation tests. This model was implemented in the river Tungabhadra of India. This worked quite well for the project at hand but showed certain irregularities. Different Quality Management methods exist currently and for this project, their impact in DO concentrations were examined based on: 1) The ability to augment the flow; 2) The ability to oxygenate the source and; 3) The ability to modify pollution loads. With the impacts realized, the study helped us understand that local oxygenation is effective when considering the increment of Do levels. There was also the understanding that a combination of the factors (flow augmentation, pollution load modification and source oxygenation) is a necessity as far as the minimum DO concentrations must be realized. With this quality model results, there is confidence that the implementation of the QUAL2Kw model will be an appropriate choice for future river water quality policies.
\end{abstract}

\section{Subject Areas}

Civil Engineering, Environmental Sciences, Hydrology

\section{Keywords}

Water Quality, Dissolved Oxygen Control, QUAL2KW, Tungabhadra River 


\section{Introduction}

The run for clear river water qualities arises due to the increasing scarcity of usable water in developing countries. In a major case, human factors have been found to be the primary factor that causes the unavailability of clear water hence the main objectives of the river basin management [1]. With the assessment and evaluation of human impacts on the quality of water as a major objective, there has been a major issue that breaches this objective. This issue is the prediction of the release of chemical substances into the river system by humans [2]. This impairs the efforts put in place to determine the impact of human activity in the aquatic ecosystem.

Human activities generate massive amounts of contaminable materials on a daily basis. They could come from agricultural, municipal or industrial sources. The materials released could be large amounts of nutrients of organic materials and their introduction into rivers or streams accelerates eutrophication processes and reduces dissolved oxygen values. This is visible during low flow periods as the values are brought below threshold figures (Figures 1-7). The effect of this is an unbalanced aquatic ecosystem resulting in the death of aquatic life. This death could stem from extreme anaerobic conditions caused by low dissolved oxygen (DO) concentrations [3].

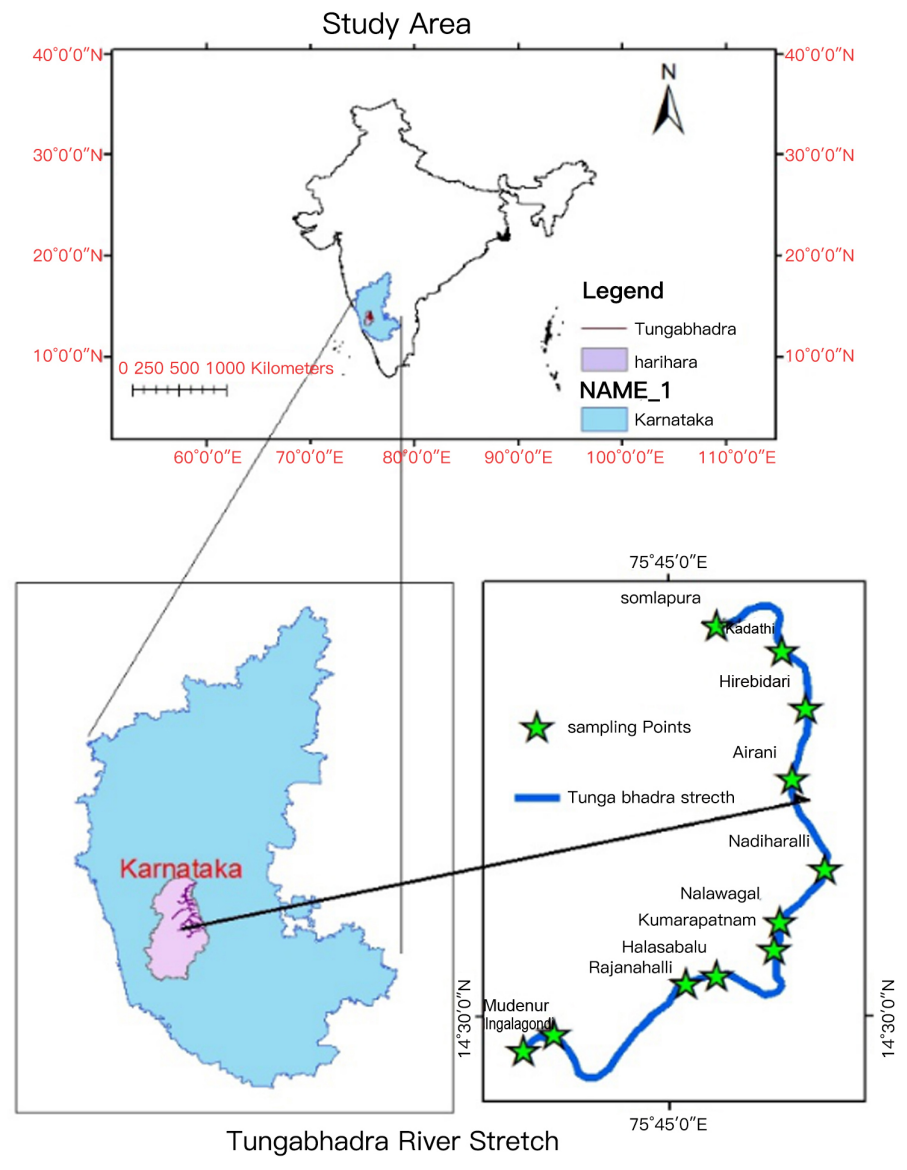

Figure 1. Sampling sites along Tungabhadra river. 


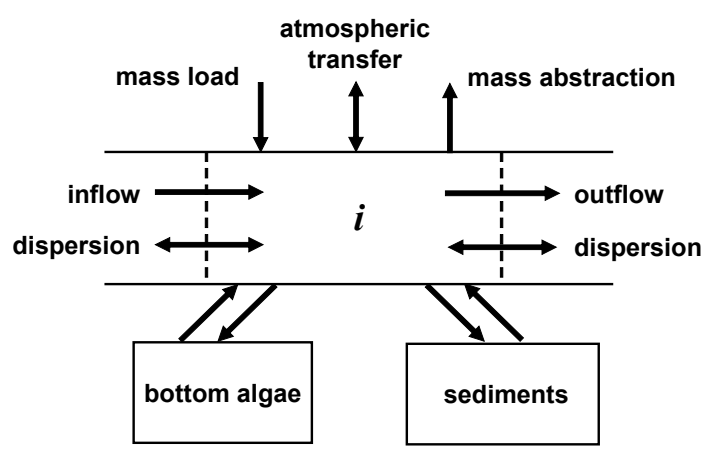

Figure 2. Mass balance equation in reach segment $i$.

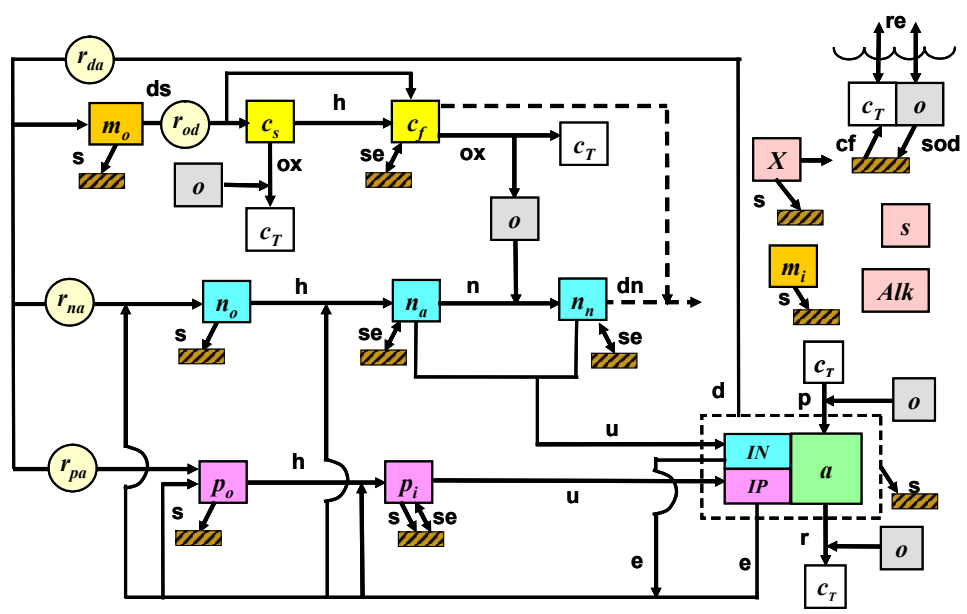

Figure 3. Model kinetics and mass transfer processes. The state variables are defined in QUAL2KW manual. Kinetic processes are dissolution (ds), hydrolysis (h), oxidation (ox), nitrification $(\mathrm{n})$, denitrification $(\mathrm{dn})$, photosynthesis $(\mathrm{p})$, respiration $(\mathrm{r})$, excretion $(\mathrm{e})$, death $(\mathrm{d})$, respiration/excretion ( $\mathrm{rx}$ ). Mass transfer processes are reaeration (re), settling (s), sediment oxygen demand (SOD), sediment exchange (se), and sediment inorganic carbon flux (cf).

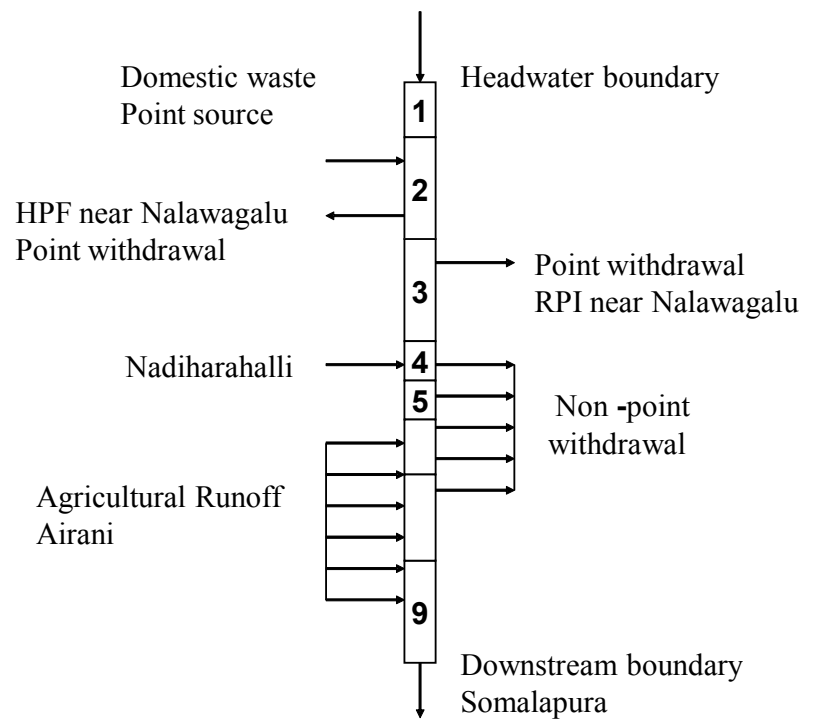

Figure 4. Segmentation scheme to calculate $K_{a}$ river. 

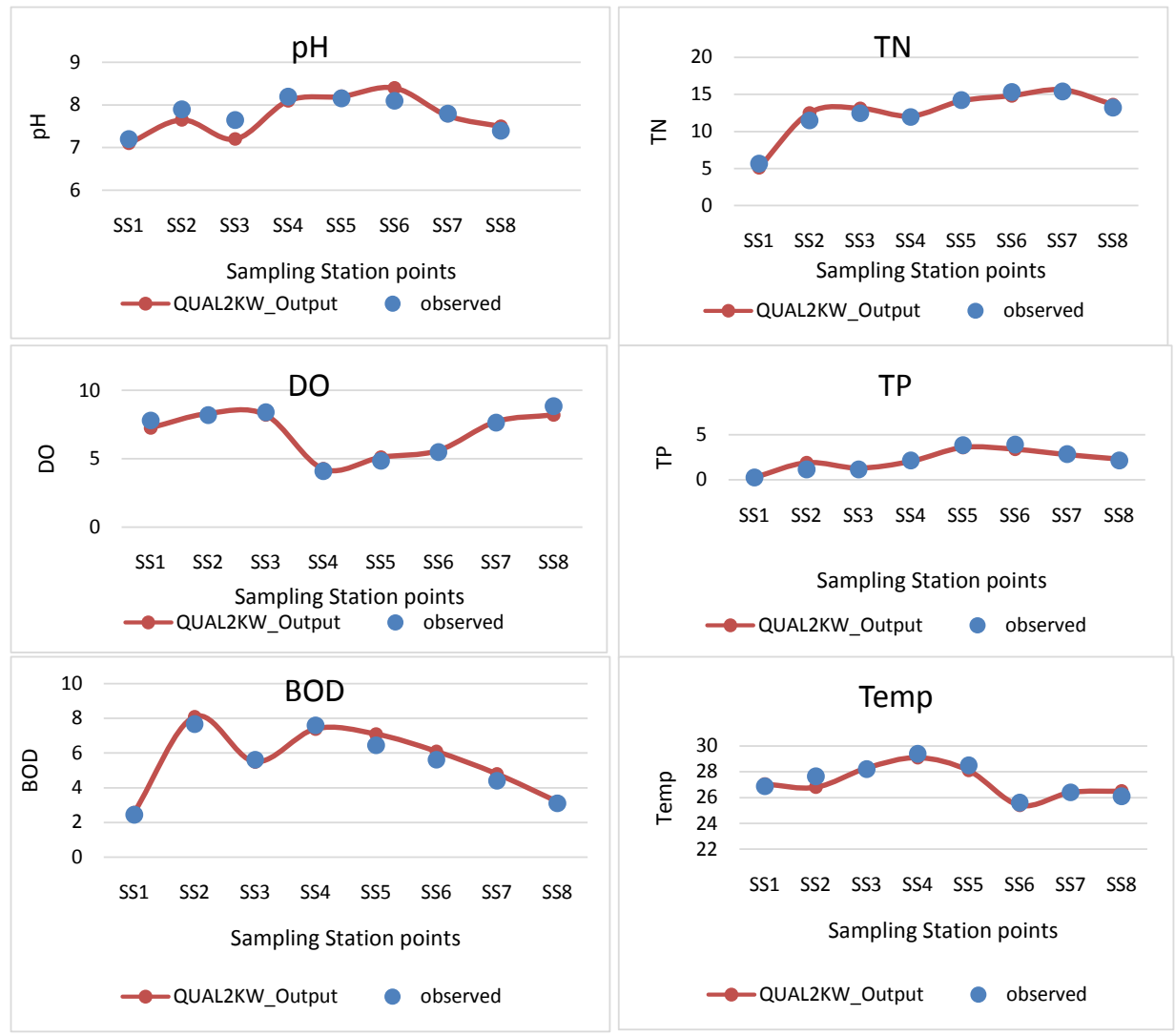

Figure 5. Calibration in Tungabhadra river for post-monsoon.

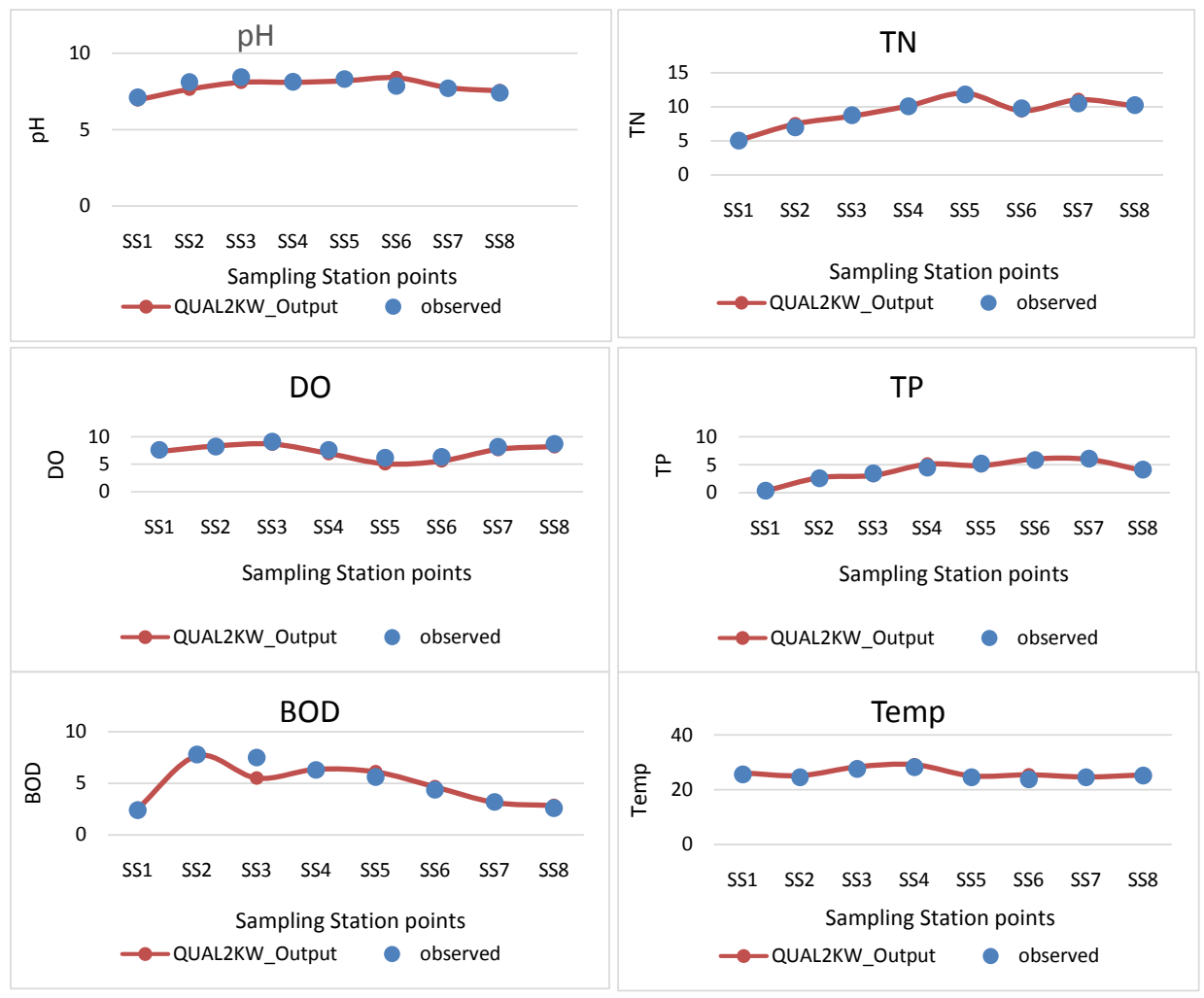

Figure 6. Validation in Tungabhadra river for pre-monsoon. 


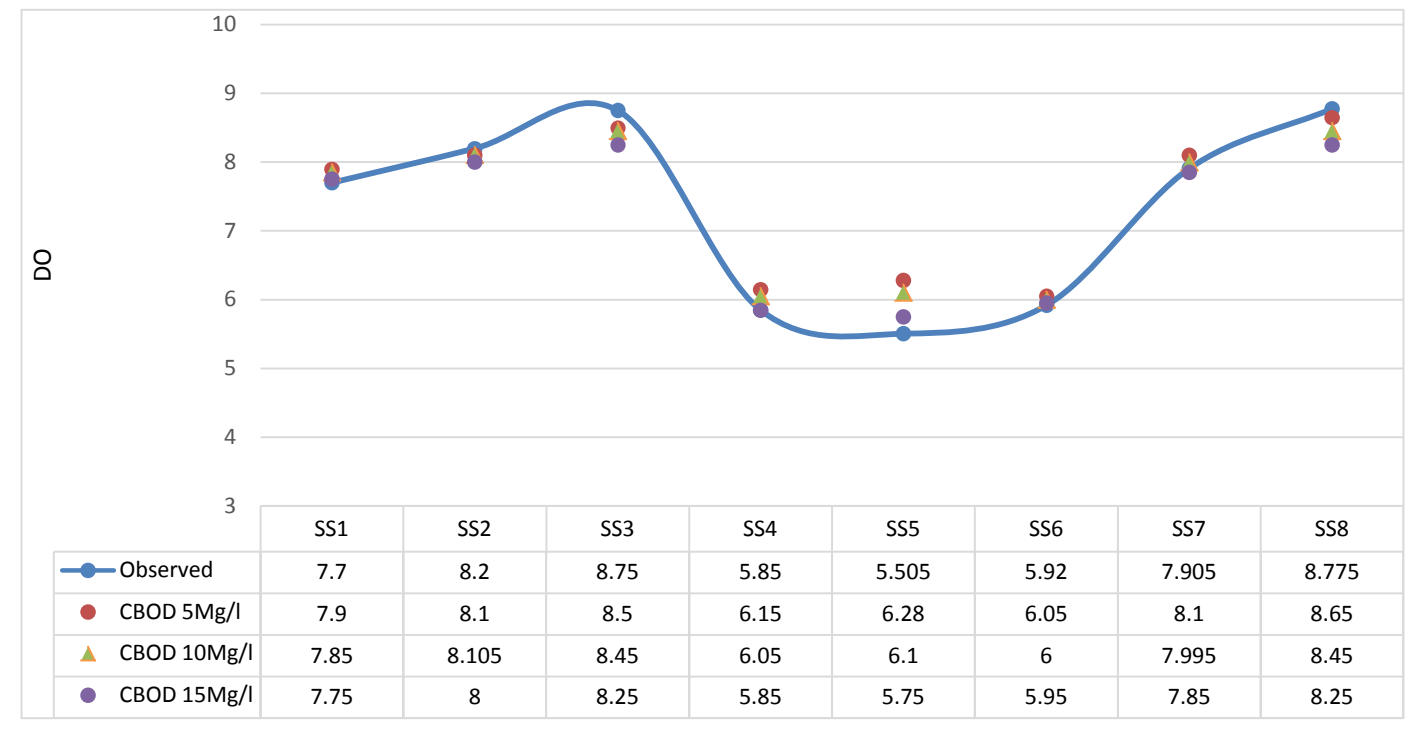

Figure 7. Dissoloved oxygen profile along river Tungabhadra with different BOD and $0.3 \mathrm{mg} / \mathrm{lN}$ limits at point load.

In a general sense, any water quality management policy should strive to maintain pollution levels below threshold levels. This will ensure minimum DO concentrations on aquatic life. A minimum DO concentration is a vital aspect when considering aquatic life. According to the [4], the acute lethal limit of DO concentration for salmonids (type of fish) is about $3 \mathrm{mg} / \mathrm{L}$. When considering the Tungabhadra river (which has varieties of aquatic life), the mild warm-water minimum can be put at about $4 \mathrm{mg} / \mathrm{L}-$ a day minimum. This is made to support less tolerant species and capricious fish inhabitants [5] [6]. The assimilative capacity of a river should be kept at the optimal level in order to achieve the desired water quality [7] and it can be touched by: 1) The application of oxygenators [7], 2) The controlling of pollution loads [8] and 3) The controlling of river flow rates [9].

Strategies of water quality management are mostly a combination of "inter-disciplinary" complex resolutions. These decisions are based on assumptions to the changing controls of water quality [10]. The linkage between waste loads and resulting water qualities can best be shown via mathematical methods [11]. The most used mathematical model to evaluate the pollution of water bodies is the QUAL2E model [12]. This model was developed by the United States Environmental protection Agency (US EPA). While this has been the case, some limitations have been listed by users and examiners of the model [13] [14] [15] [16]. A major inadequacy of this model is the unavailability of parameters to handle aspect such as conversion of algal death to carbonaceous biochemical oxygen [17] [18].

Given the erroneous nature of the QUAL2E model, it was later modified. The modifications were inclusive of an expansion to accommodate computational structures, the addition of new constituent interactions such as de-nitrification, algal BOD and DO changes. These were caused by fixed plants. After this event 
had occurred, Park and Lee in 2002 developed the QUAL2K model and in 2005, Pelletier and Chapra developed the QUAL2Kw model. The difference between this and the QUAL2K model (also developed by Chapra and Pelletier in 2003 [19] was the intention to modernize the QUAL2E model.

The QUAL2Kw model takes on new elements to optimize the water quality policy [20]. In the first instance, it makes use of two forms of carbonaceous biochemical oxygen to replace organic carbon. They are; slowly and rapidly oxidizing forms. Also, it aids the reduction of oxidation reactions to about zero at reduced oxygen levels by including anoxia and works explicitly when considering bottom algae attachments. The internal part of the model allows sediment-water changes of nutrients and dissolved oxygen, and its simulation is extended to accommodate $\mathrm{pH}$, quality of pore water (considering sedimentation) and de-nitrification.

The QUAL2Kw model is a one-dimensional model that can be implemented on the Microsoft Windows platform. It is available on the internet and can be accessed via http://www/epa.gov/-. The QUAL2Kw is a steady state stream water quality model developed to simulate constituents including the $\mathrm{pH}$, sediment oxygen demand, dissolved oxygen, ammonia nitrogen, organic phosphorus, total nitrogen, bottom algae, phytoplankton, total phosphorus, nitrite and nitrate nitrogen, temperature, carbonaceous biochemical demand, ammonia nitrogen and organic nitrogen.

The potentials of the model back the choice of the model as the framework for this study considering the Tungabhadra River. Within this study, I explain the application of the model and examine the impact of waste loads on water bodies. I also determine the utmost pollution loads that are acceptable by the stream without the violation of the least possible DO standards.

\section{Material and Methods}

\subsection{Study Area}

River Tungabhadra is a part of the Krishna basin and formed by the combination of the River Bhadra and River Tungha at Koodli which move towards down the eastern-incline of the Western-Ghats in the domain of Karnataka. The two waterways begin in MudigereTaluk of Chikmagalur District of Karnataka alongside the Nethrvathi, the Tunga and the Bhadra ascend at Gangamoola, in Varaha-Parvatha in the Western-Ghats at a height of 1198 meters (close Samse Village). From that point, the Tungabhadra walks through the fields to a distance of $531 \mathrm{~km}$. After intersection, Tungbhadra stream moves through Honnali, Harihara and Harapanahallitaluks of Davangere region. At that point, it moves through Hoovina-Hadagali, Hagari-Bomannahalli, Hospet and SiruguppaTaluks of Bellary area. In Siruguppa Taluk of Bellary location, it gets its tributary Vedavathi River. The waterway shapes characteristic limit among Bellary and Koppal district and after that among Bellary and Raichur locale along its course. In the wake of entering Andhra Pradesh State, it moves through sanctuary town of Mantralaya and after that through Kurnool Taluk. Its rise from the ocean level is 
$539 \mathrm{~m}$ and the co-ordinates are $14.52^{\circ} \mathrm{N}$ and $75.8^{\circ} \mathrm{E}$. Population of the Harihara city preliminary at 2011 was 85,600 (as per census) and the anticipated population for 2018 is 110,000 .

This study covers a $40.05 \mathrm{~km}$ stretch of river starting $18 \mathrm{~km}$ upstream of Harihara town to about $22.5 \mathrm{~km}$ downstream. Stream water samples were Collected. from seven sampling-station viz. Mudenuru (SS1), Rajanahalli (SS2), Kumarapatnam bridge (SS3), Nalawagal (SS4), Nadhiharalli (SS5), Airani (SS6) and Heribedri and Kadathi (SS7), and Somalapura (SS8) with populations ranging from 45,000 to 55,000, are located on the bank of this river at the Upstream and downstream of Harihara town. For all these villages and Harihara town, this river is a primary source of drinking water.

The river about two to three decades ago was in a drinkable state. It was deemed pure in both physical and ritual forms. This is however, no more feasible. Ritual practices such as bathing, etc. are almost extinct due to the level of pollution in the river [5]. The number of aquatic life in this holy river has also reduced drastically as it receives an enormous discharge of domestic and industrial effluent [21]. It is thus labeled biologically dead. It is because of occurrences such as this that made the selection of the $40.5 \mathrm{~km}$ stretch of the Tungabhadra river feasible for this study.

\subsection{Data and Monitoring Sites}

Data for this study was collated between the $9^{\text {th }}$ and $19^{\text {th }}$ of June, 2018 as well as between the $2^{\text {nd }}$ and $3^{\text {rd }}$ of December, 2018. This counts as pre and post monsoon periods for the Tungabhadra river and its tributaries. The maximum number of hours spent was about 30 .

During the pre-monsoon season, sample events were set in order to monitor low flows at their critical state. Data pulled for this included air temperature, wind speed, relative humidity counted at meteorological data and they were obtained from the Department of Meteorology and Hydrology. Major points used for monitoring along the river include, sampling Station 1 (Ingalagondi and Mudenuru, chainage) at near to Jack well point, sampling Station 2 (Rajanahalli village) adjacent to Temple road, sampling Station 3 (Kumarapatanam bridge) at wastewater discharge from Harihara and Kumarapatanam town, sampling Station 4 (Nalavagalu) at near to HariharaPolyfiber discharge, sampling Station 5 (Nadiharahalli) at just near from Nalavagal, sampling Station 6 (Airani) at just downstream of Temple, sampling Station 7 (Heribidri) at just downstream of confluence with sugarcane factory waste molasses and sampling Station 8 (Somalapura) at just downstream of temple. Observations were made between stations Rajanahalli and Kumarapatanam at about $8.000 \mathrm{~km}$ chainage and the quantities of water abstractions noted were about $0.14 \mathrm{~m}^{3} / \mathrm{s}$ in pre-monsoon and $0.36 \mathrm{~m}^{3} / \mathrm{s}$ in post-monsoon periods (Tables $1-5$ ).

\subsection{Sampling and Analysis}

The parameters examined for water quality included; Temperature, $\mathrm{pH}$, dissolved 
Table 1. Water quality of surface water along Tungabahadra river in premonsoon.

\begin{tabular}{|c|c|c|c|c|c|c|c|c|c|c|c|}
\hline Sampling station & Temp & $\mathrm{pH}$ & $\mathrm{DO}$ & $\mathrm{BOD}$ & $\mathrm{TN}$ & $\mathrm{TP}$ & Organic-N & $\mathrm{NO}_{3}-\mathrm{N}$ & $\mathrm{NH}_{4}-\mathrm{N}$ & Organic-P & Inorganic-p \\
\hline & & & $\mathrm{mg} / \mathrm{l}$ & $\mathrm{mg} / \mathrm{l}$ & $\mathrm{mg} / \mathrm{l}$ & $\mathrm{mg} / \mathrm{l}$ & $\mathrm{mg} / \mathrm{l}$ & $\mathrm{mg} / \mathrm{l}$ & $\mathrm{mg} / \mathrm{l}$ & $\mu \mathrm{g} / \mathrm{l}$ & $\mu \mathrm{g} / \mathrm{l}$ \\
\hline SS1 & \multirow{8}{*}{28} & 7.2 & 7.8 & 2.44 & 5.65 & 0.27 & 0.43 & 0.19 & 5.03 & 184.1 & 85.9 \\
\hline SS2 & & 7.9 & 8.2 & 7.68 & 11.48 & 1.17 & 2.465 & 1.385 & 7.63 & 26.18 & 905.8 \\
\hline SS3 & & 7.65 & 8.4 & 5.62 & 12.45 & 1.15 & 2.27 & 1.88 & 8.3 & 876 & 624 \\
\hline SS4 & & 8.2 & 4.1 & 7.6 & 11.95 & 2.15 & 1.66 & 1.89 & 8.4 & 1053.5 & 1096.5 \\
\hline SS5 & & 8.16 & 4.85 & 6.45 & 14.23 & 3.84 & 2.42 & 2.2 & 9.6 & 1167.4 & 2627.5 \\
\hline SS6 & & 8.1 & 5.5 & 5.62 & 15.32 & 3.9 & 3.62 & 2 & 9.7 & 1095.9 & 2804.1 \\
\hline SS7 & & 7.8 & 7.65 & 4.4 & 15.4 & 2.85 & 3.14 & 1.96 & 10.3 & 883.5 & 1966.5 \\
\hline SS8 & & 7.4 & 8.85 & 3.1 & 13.2 & 2.16 & 2.44 & 2.36 & 8.4 & 475.2 & 1684.8 \\
\hline
\end{tabular}

Table 2. Water quality of surface water along Tungabahadra river in postmonsoon.

\begin{tabular}{|c|c|c|c|c|c|c|c|c|c|c|c|}
\hline Sampling station & Temp & $\mathrm{pH}$ & $\mathrm{DO}$ & $\mathrm{BOD}$ & $\mathrm{TN}$ & $\mathrm{TP}$ & Organic-N & $\mathrm{NO}_{3}-\mathrm{N}$ & $\mathrm{NH}_{4}-\mathrm{N}$ & Organic-P & Inorganic-p \\
\hline & & & $\mathrm{mg} / \mathrm{l}$ & $\mathrm{mg} / \mathrm{l}$ & $\mathrm{mg} / \mathrm{l}$ & $\mathrm{mg} / \mathrm{l}$ & $\mathrm{mg} / \mathrm{l}$ & $\mathrm{mg} / \mathrm{l}$ & $\mathrm{mg} / \mathrm{l}$ & $\mu \mathrm{g} / \mathrm{l}$ & $\mu \mathrm{g} / \mathrm{l}$ \\
\hline SS1 & \multirow{8}{*}{25.1} & 7.1 & 7.6 & 2.4 & 5.05 & 0.37 & 0.6 & 0.35 & 0.95 & 116.9 & 253.1 \\
\hline SS2 & & 8.1 & 8.2 & 7.8 & 6.99 & 2.6 & 1.23 & 0.61 & 1.84 & 1674.4 & 925.6 \\
\hline SS3 & & 8.43 & 9.1 & 7.5 & 8.77 & 3.48 & 1.6 & 0.74 & 2.34 & 1057.9 & 1990.1 \\
\hline SS4 & & 8.12 & 8.1 & 6.3 & 10.11 & 4.48 & 1.74 & 0.68 & 2.42 & 1617.3 & 2862.1 \\
\hline SS5 & & 8.3 & 6.16 & 5.62 & 11.84 & 5.23 & 2.65 & 0.83 & 3.48 & 3059.55 & 2170 \\
\hline SS6 & & 7.85 & 6.34 & 4.37 & 9.8 & 5.85 & 2.09 & 0.74 & 2.83 & 3591.9 & 2258 \\
\hline SS7 & & 7.7 & 8.16 & 3.2 & 10.51 & 6.1 & 1.67 & 0.45 & 2.12 & 1210.4 & 4889.6 \\
\hline SS8 & & 7.4 & 8.7 & 2.6 & 10.26 & 4.15 & 1.1 & 0.76 & 1.86 & 938.315 & 3211.68 \\
\hline
\end{tabular}

Table 3. River hydraulic characteristics for Tungabhadra river.

\begin{tabular}{ccccccccc}
\hline season & \multicolumn{2}{c}{ velocity } & \multicolumn{2}{c}{ depth } & flow & velocity & depth \\
\hline \multirow{2}{*}{ coefficient } & exponent & coefficient & exponent & $\mathrm{m} 3 / \mathrm{s}$ & $\mathrm{m} / \mathrm{s}$ & $\mathrm{m}$ \\
\hline premonsoon & 0.408 & 0.365 & 0.318 & 0.459 & 0.76 & 0.37 & 0.28 \\
postmonsoon & 0.389 & 0.373 & 0.112 & 0.714 & 5.51 & 0.73 & 0.585 \\
\hline
\end{tabular}

Table 4. Composition (\%) nitrogen and phosphorus at sampling sites along Tungabhadra river.

\begin{tabular}{cccccc}
\hline sampling station & organic-P & Inorganic-P & Organic-N & $\mathrm{NO}_{3}-\mathrm{N}$ & $\mathrm{NH}_{4}-\mathrm{N}$ \\
\hline SS1 & 49.88989 & 50.11011 & 9.745904 & 5.146762 & 85.10733 \\
SS2 & 33.3188 & 66.6812 & 19.53435 & 10.39561 & 70.07005 \\
SS3 & 53.28667 & 46.71333 & 18.23847 & 11.76913 & 69.59331 \\
SS4 & 42.55022 & 57.44978 & 15.55095 & 11.27096 & 73.1781 \\
SS5 & 44.45052 & 55.54948 & 19.69404 & 11.23522 & 69.24676 \\
SS6 & 44.75 & 55.25 & 22.47789 & 10.30293 & 69.41307 \\
SS7 & 25.42131 & 74.57869 & 18.13962 & 8.504455 & 73.35593 \\
SS8 & 22.305 & 77.695 & 14.60305 & 12.6431 & 72.75385 \\
Average Values & 39.49655 & 60.50345 & 17.24803 & 10.15852 & 72.8398 \\
\hline
\end{tabular}


Table 5. Calibration system parameters in the Tungabhadra river.

\begin{tabular}{|c|c|c|c|c|}
\hline \multicolumn{3}{|c|}{ Adopted } & \multirow{2}{*}{$\begin{array}{c}\text { Minimum } \\
\text { values }\end{array}$} & \multirow{2}{*}{$\begin{array}{c}\text { Maximum } \\
\text { values }\end{array}$} \\
\hline Parameter & values & Units & & \\
\hline Carbon. & 40 & $\mathrm{gC}$ & 40 & 40 \\
\hline Nitrogen. & 7.2 & $\mathrm{gN}$ & 7.2 & 7.2 \\
\hline Phosphorus. & 1 & $\mathrm{gP}$ & 1 & 1 \\
\hline Detritus dry weight. & 100 & $\mathrm{gD}$ & 100 & 100 \\
\hline Chlorophyll-a. & 1 & gA & 1 & 1 \\
\hline Slow CBOD hydrolysis rate. & 3.83 & /day & 0 & 5 \\
\hline Slow CBOD oxidation rate. & 2.48 & /day & 0.04 & 4.2 \\
\hline Fast CBOD oxidation rate. & 3.2 & /day & 0.02 & 4.2 \\
\hline Organic $\mathrm{N}$ hydrolysis. & 0.4 & /day & 0.02 & 0.4 \\
\hline Organic $\mathrm{N}$ settling velocity. & 0.1 & $\mathrm{~m} /$ day & 0.001 & 0.1 \\
\hline Ammonium nitrification. & 9.53 & /day & 0 & 10 \\
\hline Nitrate de-nitrification. & 1.48 & /day & 0 & 2 \\
\hline $\begin{array}{l}\text { Sediment de-nitrification } \\
\text { transfer coefficient. }\end{array}$ & 0.94 & $\mathrm{~m} /$ day & 0 & 1 \\
\hline Organic P hydrolysis. & 0.7 & /day & 0.01 & 0.7 \\
\hline Organic $\mathrm{P}$ settling velocity. & 0.003 & $\mathrm{~m} /$ day & 0.001 & 0.1 \\
\hline Inorganic $\mathrm{P}$ settling velocity. & 0.13 & $\mathrm{~m} /$ day & 0 & 2 \\
\hline $\begin{array}{l}\text { Sediment } \mathrm{P} \text { oxygen attenuation } \\
\text { half saturation constant. }\end{array}$ & 1.88 & $\mathrm{mgO}_{2} / \mathrm{L}$ & 0 & 2 \\
\hline \multicolumn{5}{|l|}{ Bottom Algae: } \\
\hline Max growth rate. & 106.1 & $\mathrm{mgA} / \mathrm{m} 2 /$ day or /day & 0 & 500 \\
\hline Respiration rate. & 0.31 & /day & 0.05 & 0.5 \\
\hline Excretion rate. & 0.43 & /day & 0 & 0.5 \\
\hline Death rate. & 0.008 & /day & 0 & 0.5 \\
\hline External nitrogen half sat constant. & 33.83 & $\mu \mathrm{gN} / \mathrm{L}$ & 10 & 300 \\
\hline External phosphorus half sat constant. & 30.12 & $\mu \mathrm{gP} / \mathrm{L}$ & 1 & 50 \\
\hline Light constant. & 40.76 & langleys/day & 1 & 100 \\
\hline Ammonia preference. & 71.81 & $\mu \mathrm{gN} / \mathrm{L}$ & 1 & 100 \\
\hline Subsistence quota for nitrogen. & 6.06 & $\mathrm{mgN} / \mathrm{mgA}$ & 0.0072 & 7.2 \\
\hline Subsistence quota for phosphorus. & 0.3 & $\mathrm{mgP} / \mathrm{mgA}$ & 0.001 & 1 \\
\hline Maximum uptake rate for nitrogen. & 80.59 & $\mathrm{mgN} / \mathrm{mgA} /$ day & 1 & 500 \\
\hline Maximum uptake rate for phosphorus. & 490.42 & $\mathrm{mgP} / \mathrm{mgA} /$ day & 1 & 500 \\
\hline Internal nitrogen half sat ratio. & 2.06 & Dimensionless & 1.05 & 5 \\
\hline Internal phosphorus half sat ratio. & 1.88 & Dimensionless & 1.05 & 5 \\
\hline
\end{tabular}

oxygen (DO), 5 days' biochemical oxygen demand (BOD), Total nitrogen (TN), Total phosphorus (TP), Nitrite + Nitrate-nitrogen $\left(\mathrm{NO}_{3}-\mathrm{N}\right)$, Organic-nitrogen 
(Organic-N), Ammonia-nitrogen $\left(\mathrm{NH}_{4}-\mathrm{N}\right)$, Organic Phosphorus (Organic-P), Inorganic Phosphorus (Inorganic-P), River flow $(\mathrm{Q})$, River velocity $(\mathrm{m})$ and River water depth $(\mathrm{m})$. The float method was used to measure floatation. This was determined via the consideration of cross-sections and the measuring of velocities at $3-5$ pints along river cross-sections. The parameters in this study were expressed in $\mathrm{mg} / \mathrm{L}$ or $\mu \mathrm{g} / \mathrm{L}$. All parameters except $\mathrm{pH}$, temperature $\left({ }^{\circ} \mathrm{C}\right)$, velocity $(\mathrm{m})$, depth $(\mathrm{m})$ and flow $\left(\mathrm{m}^{3} / \mathrm{s}\right)$. Also, standard methods were applied during sampling preservation, transportation and analysis of water samples (APHA, 1989). During analysis for temperature and $\mathrm{pH}$, the tools used were the portable thermometer and the $\mathrm{pH}$-meter respectively. The remaining parameters were analyzed thus; DO was measured with a portable DO probe and in the laboratory by titration. $\mathrm{BOD}$ and $\mathrm{CBOD}$ were determined by azide modification method (5 days' incubation period at $20^{\circ} \mathrm{C}$ ). TP was analyzed via digestion + ammonium molybdenum blue method. The samples in quote were digested with concentrated nitric + sulphuric acids before analysis of phosphate. This was necessary to convert phosphates into orthophosphates form. TN was analyzed by the determination of Nitrite-N, Nitrate-N and Total Kjeldahl Nitrogen (TKN). Nitrite- $\mathrm{N}$ was analyzed by spectrophotometric method (diazo method). TKN was analysed using macro-kjeldahl method by following titration with standard hydrochloric acid. Ammonia nitrogen was analyzed by nesslerization method and by titration. Organic- $\mathrm{N}$ was analysed by the subtraction of the observed value of ammonia nitrogen from TKN [22].

\subsection{Modeling Tool}

With QUAL2Kw, there is the possibility to check the concentration $c i$ within the water columns. This is because the model has a general mass balance equation. This though does not work for hyporheic concentrations. In using the general mass balance equation, parameters representing transport and loading are likely to be omitted while the column could be considered to be of reach $I$ [20] [21]. During auto-calibration for the QUALK2w model, we get to employ the genetic algorithm (GA). This step is a necessity if we desire to achieve a well-placed goodness of fit for the model. The results obtained from this algorithm can then be compared with the measured data. When carrying out the comparison, we adjust the parameters used. These parameters are usually large in numbers [20]. The determination of the best goodness of fit for the model can be done as a reciprocal for the weighted average of the RMSE. RMSE refers to the root mean squared error. It must be normalized before the weighted average can be considered.

$\frac{\mathrm{d} c_{i}}{\mathrm{~d} t}=\frac{Q_{i-1}}{V_{i}} c_{i-1}-\frac{Q_{i}}{V_{i}} c_{i}-\frac{Q_{a b, i}}{V_{i}} c_{i}+\frac{E_{i-1}^{\prime}}{V_{i}}\left(c_{i-1}-c_{i}\right)+\frac{E_{i}^{\prime}}{V_{i}}\left(c_{i+1}-c_{i}\right)+\frac{W_{i}}{V_{i}}+S_{i}+\frac{E_{h y p, i}^{\prime}}{V_{i}}\left(c_{2, i}-c_{i}\right)(1)$

where $W_{i}=$ the external loading of the constituent to reach $i[\mathrm{~g} / \mathrm{d}$ or $\mathrm{mg} / \mathrm{d}]$, and $S_{i}=$ sources and sinks of the constituent due to reactions and mass transfer mechanisms $\left[\mathrm{g} / \mathrm{m}^{3} / \mathrm{d}\right.$ or $\left.\mathrm{mg} / \mathrm{m}^{3} / \mathrm{d}\right]$. Exchange of mass between the surface water and 
the hyporheic sediment zone is represented by the bulk hyporheic exchange flow in reach $i\left[E_{h y p, i}^{\prime}\right.$ in $\mathrm{m}^{3} /$ day] and the difference in concentration in the surface water $\left(c_{i}\right)$ and in the hyporheic sediment zone $\left(c_{2, i}\right)$.

\subsection{River Discretization}

During this study, the total length of the Tungabhadra river $(40.5 \mathrm{~km})$ was discretized into 81 reaches of $0.5 \mathrm{~km}$ each. The model then makes use of the headwater to define the boundary condition upstream. The segment of the river treated as headwater was the sampling station " 1 " while internal calculation was used to represent the boundary condition downstream. The hydraulic features for each of the sampling locations were determined using measured river geometries and velocities. With this, the model was able to allow the input of the river reach hydraulic characteristics (coefficients and exponents of velocity and depth) as empirical equations to estimate average water velocity $(V)$ and depth $(D)$ of the river. During the pre and post-monsoon seasons, flows, mean depths and velocities were measured and used to compute the coefficients $a, c$ and exponents $b, d$.

Define abbreviations and acronyms the first time they are used in the text, even after they have been defined in the abstract. Abbreviations such as IEEE, SI, MKS, CGS, sc, dc, and rms do not have to be defined. Do not use abbreviations in the title or heads unless they are unavoidable.

\subsection{Input Data}

As earlier explained, the water quality input parameters measured included flow, temperature, $\mathrm{pH}, \mathrm{DO}, \mathrm{BOD}$, organic nitrogen, ammonia nitrogen, nitrite + nitrate nitrogen, organic phosphorus and inorganic phosphorus. Data on inorganic suspended solids, conductivity, fast CBOD, phytoplankton, detritus and pathogen were however not measured. When carrying analysis, a default value was adopted. Other inputs to the model included wastewater, groundwater, river tributaries and abstraction.

Majorly, the inputs required for the model come from the families of nitrogen and phosphorus. This set off data was not measured in the pre-monsoon season however the post-monsoon survey was considered in the extraction of these data. According to [6], during base-flow in Melbourne (urban storm water), total nitrogen was found to consist Organic- $\mathrm{N} 36 \%, \mathrm{NH}_{4}-\mathrm{N} 9 \%, \mathrm{NO}_{2}+\mathrm{NO}_{3}-\mathrm{N} 39 \%$ and particulate Organic-N 16\%. What this showed was that the nitrogen composition did not vary between sites. The proof for this was in the amount of total dissolved nitrogen. It was found that it comes out to be Organic-N $42.9 \%, \mathrm{NH}_{4}-\mathrm{N}$ $10.7 \%$ and $\mathrm{NO}_{2}+\mathrm{NO}_{3}-\mathrm{N} 46.49 \%$.

A survey on international researches put the composition of total nitrogen at Organic-N 71\% $\mathrm{NH}_{4}-\mathrm{N} 5 \%$ and $\mathrm{NO}_{2}+\mathrm{NO}_{3}-\mathrm{N} 24 \%$. Organic-N was found to be a major constituent in international literatures (Organic-N) [6]. If we are to consider the Melbourne data in which particulate nitrogen accounts for $16 \%$, Or- 
ganic- $\mathrm{N}$ will account for $55 \%$. The composition of total dissolved nitrogen is $65.5 \% \mathrm{NH}_{4}-\mathrm{N} 6 \%$ and $\mathrm{NO}_{2}+\mathrm{NO}_{3}-\mathrm{N} 28.5 \%$. According to another survey performed by Kucuksezgin et al. (2005), the composition of total dissolved nitrogen and phosphorus are given to be Organic nitrogen 88.5\%, $\mathrm{NH}_{4}-\mathrm{N} 3.7 \%$ and $\mathrm{NO}_{2}$ $+\mathrm{NO}_{3}-\mathrm{N} 7.8 \%$; Organic-P $81.1 \%$ and Inorganic-P $18.9 \%$, respectively. In the Tungabhadra river however, the average compositions of TP were Organic-P $39.5 \%$ and Inorganic-P $60.5 \%$ while the average compositions of TN were Organic- $\mathrm{N} 17.24 \%, \mathrm{NH}_{4}-\mathrm{N} 72.83 \%$ and Nitrite + Nitrate-N $10.15 \%$. Given the differences in the compositions of nutrients, the proportions derived along the Tungabhadra river were used in the modeling.

In this study, I used sets of equations to act as processes for the QUALK2w model. The processes in the model could be physical, biological or chemical. The parameters within these are usually numerous. Surveys were made in respect to the rating for usable parameters. Choices made were dependent on results obtained from sources such as the Environmental Protection Agency, the QUAL2Kw user manual (Pelletier and Chapra, 2005) and Documentation for the enhanced stream water quality model QUAL2E and QUAL2E-UNCAS [12]. A number of options could be considered when calculating re-aeration using QUAL2Kw model. For the purpose of this study, it is calculated as a function of river hydraulics using the Owens-Gibbs formula [23]. The formula according to [24] can be used effectively when working with water bodies that have depths up to 0.4 $11 \mathrm{ft}$. They also are useful when working with water bodies that have velocities that range from $0.1-5 \mathrm{ft} / \mathrm{s}$. the CBOD oxidation rate for the study was however placed within the range $0.04-4.2$.

\subsection{System Parameter}

The physical, chemical, and biological processes stimulated by QUAL2Kw represented by a set of equations contain many parameters Table 5 . The ranges of model rate parameters were obtained from various literatures including Environmental Protection Agency (EPA) guidance document [25], QUAL2Kw user manual [21] and Documentation for the enhanced stream water quality model QUAL2E and QUAL2E-UNCAS [12]. QUAL2Kw has eight options to calculate re-aeration rate as a function of the river hydraulics. We have used Owens-Gibbs formula [23], which was developed for streams exhibiting depths ranging from 0.4 to 11 feet and velocities ranging from 0.1 to 5 feet/s [24]. The range of CBOD oxidation rate was assumed as $0.04-4.2$ as in 36 rivers in USA [26]. The settling of $\mathrm{CBOD}$ is considered insignificant. The ranges of other parameters were assumed default as in QUAL2Kw.

\subsection{Model Implementation}

Data gotten from the post-monsoon period were used for calibration. The time step for this was left at $5.625 \mathrm{~min}$. This aided the avoidance of instability within the model. During integration, Euler's method was used and the goodness of fit 
was done using different weights assigned to varying parameters. The weights considered were found to reduce the errors between measures and modeled parameter values. The most influential parameter for the model was the weight for $\mathrm{DO}$ and it was given as 10 . Other parameters such as TN, TP, temperature, BOD, $\mathrm{pH}$ were given values of 2 while others assumed 1 .

The model was looped until proper adjustment was obtained for the parameters. This process also aided the achievement of an agreement between the results as well as the measurements. The population sixe used during the model run was 100 and the generation span was 50. According to [20] the population size of 100 offers better performance as that of 500 .

Without changing the calibrated parameters, the model was run on data sets different from the ones taken during the pre-monsoon period. This was necessary to test the ability of the calibrated model in order to effectively predict the water quality under varying conditions. After this had been concluded, the calibrated model could then be used to experiment on water quality conditions during critical periods in the period.

\section{Result and Discussion}

\subsection{Calibration and Validation}

The model calibration for the water quality was monitored from six locations. The results gotten from the calibrations are similar to measured data-with the presence of some irregularities. From these results, the standard error (between the observed and simulated values) are $11.2 \%, 18.3 \%$ and $13.55 \%$ for flow, depth and velocity respectively. The effectiveness and interrelationships between the values are expressed by $R^{2}$ and they are $0.95,0.82$ and 0.84 respectively. The relative mean errors together with values for $\mathrm{R}^{2}$ are given thus; $25.62 \%(0.979)$, $31.1 \%$ (0.98), 44.4\% (0.98), 30.5\% (0.948), 24.13\% (0.96) and 17\%. these values represent $\mathrm{DO}, \mathrm{BOD}, \mathrm{TN}, \mathrm{TP}$, temperature and $\mathrm{pH}$. After simulations, the results show that the water qualities of the Tungabhadra river do not meet the minimum DO standard ( $4 \mathrm{mg} / \mathrm{L}$ beyond $18 \mathrm{~km}$ ). In the upper segment of the river, there is an indication of better water quality as the DO stands at $5 \mathrm{mg} / \mathrm{L}$. This owes to the presence of sewers to manage domestic, industrial and rain wastewater. Collected wastewater can be treated and dumped back into the river at a different section-say $17.05 \mathrm{~km}$. The dumped packages can be seen later at about $13-17 \mathrm{~km}$ and $18-21 \mathrm{~km}$. the positioning of the packages can be given as; Package 1: $13.5 \mathrm{~km}$ and Package 2: $7.05 \mathrm{~km}-8.2 \mathrm{~km}$.

Past $12 \mathrm{~km}$, the concentration of dissolved oxygen decreases gently till it reaches a minimum of $14.25-15.25 \mathrm{~km}$. This is due to the presence of a high level of pollution (industrial waste). Re-aeration coefficient was found to be low due to the increase in the velocities. Also, past $25.25 \mathrm{~km}$, there is a gentle increase in the concentration of dissolved oxygen. This is due to the increase in the addition of increased DO water from sampling station 5 and re-aeration.

Aside these, there is also an increase in the concentration of total potassium, 
total nitrogen and CBOD. This occurs $18 \mathrm{~km}$ due to discharge of local waste water drains and treatment plant effluent. The simulation shows that there is significant difference between the modeled and measured values. The difference is partly because of the non-inclusion of pollution effective materials such as harihara poly fiber and Grism industry.

The validated results for the model have some exceptions. For example, the SE and $\mathrm{R}^{2}$ values: $53.25 \%$ (0.98), 42.65\% (0.93), 23.5\% (0.978), 25.93\% (0.95), 63.15\% (0.95) and $22 \%$ for $\mathrm{DO}, \mathrm{BOD}, \mathrm{TN}, \mathrm{TP}$, temperature and $\mathrm{pH}$ respectively are between the simulated and observed values. These values despite the differences are acceptable for developing countries when considering the financial resources for these countries and the higher accuracy of data analysis.

\subsection{Strategies for Water Quality Control}

Point sources also influence DO concentrations along the river. Point sources include wastewater treatment plants, local sewers and river tributaries. The influence of the point sources was evaluated using a validated model during the pre-monsoon period. This was in difference to the 7-day consecutive low flow with a 10 year return frequency. During the evaluation, there was the assumption of the absence of water leakage from sewers and the consideration of the following:

1) Pollution loads modification

2) Flow Augmentation and

3) Local oxygenation.

\subsection{Modification of Pollution Loads}

Throughout the duration of the study, point sources used were assigned fixed trial values. The values were CBOD as $15 \mathrm{mg} / \mathrm{L}, 10 \mathrm{mg} / \mathrm{L}, 5 \mathrm{mg} / \mathrm{L}$ and $\mathrm{TN}$ as 0.3 $\mathrm{mg} / \mathrm{L}$. The point sources were from the Tungabhadra river and there was the assumption of modification for the waste water treatment plants. This was effected successfully due to the enforcement of policies in respect to this purpose. All dissolved oxygen did not however meet the minimum requirements of $4 \mathrm{mg} / \mathrm{L}$.

\subsection{Augmentation of Flow}

In this research work we are assuming that augmenting the flow of pollution loads was feasible upon conclusion of water supply projects in Karnataka. For that project is estimated to supply about $3.1 \mathrm{~m}^{3} / \mathrm{s}$ of water to the Tungabhadra river. In addition, none of the dissolved oxygen profiles actually equal the requirements.

\subsection{Local Oxygenation}

The effects of oxygenators along critical points of the river produces strong oxygenation through air entrainment. The amount of dissolved oxygen coming into a place can be figured out via the implementation of an empirical equation. The 
equation relates the Do deficit above and below dam to the geometrical properties of the weir, weir type, quality of water and water temperature. The weirs were used to evaluate the effects of the oxygenators. Upon the conclusions of simulations, three primary points were discovered. The points- $12.5 \mathrm{~km}, 13.5$ $\mathrm{km}$ and $14.5 \mathrm{~km}$-were found suitable for the installment of the weirs. The approximate heights needed for the weirs were about $1.35 \mathrm{~m}$ at $12.5 \mathrm{~km}$ and each $0.75 \mathrm{~m}$ at $13.5 \mathrm{~km}$ and $14.5 \mathrm{~km}$ locations. With this in place, it is now possible to meet the minimum DO concentrations. This can be done by limiting the flow of augmentation with $5 \mathrm{mg} / \mathrm{L} \mathrm{CBOD}$. This however does not work at point 12.25 $\mathrm{km}$ in which DO concentration is $2.4 \mathrm{mg} / \mathrm{L}$. The reductions in the concentration of dissolved oxygen observed at points $12.25 \mathrm{~km}, 13.25 \mathrm{~km}$ and $14.25 \mathrm{~km}$ can be sad to be due the effect of weirs at $12.5 \mathrm{~km}, 13.5 \mathrm{~km}$ and $14.5 \mathrm{~km}$ respectively. This by extension increases the depth of the water and inversely acts on the aeration coefficient behind the dams.

\section{Summary}

With data pulled during 2018, the QUAL2Kw model was calibrated and tested for the Tungabhadra River. The model was suitable for the task to be done although there were inconsistencies. During calibration, the $S E$ and $\mathrm{R}^{2}$ values between the simulated and measured data for DO, BOD, TN, TP, temperature and $\mathrm{pH}$ were $25.62 \%$ (0.979), $31.1 \%$ (0.98), $44.4 \%$ (0.98), $30.5 \%$ (0.948), $24.13 \%$ (0.96) and $17 \%$. Upon validation, these values were discovered to be $53.25 \%$ (0.98), $42.65 \%$ (0.93), 23.5\% (0.978), 25.93\% (0.95), 63.15\% (0.95) and $22 \%$ and $15 \%$ respectively.

In this study, the QUAL2Kw model was implemented in order to simulate different strategies when considering water management. This was done based on some factors including; flow augmentation, local oxygenation and pollution loads modification. With the results obtained, it can be said that local oxygenation is effective in raising dissolved oxygen levels. Also, it is seen that a combination of wastewater modification, flow augmentation and local oxygenation can be used to ensure the requirements for the minimum DO concentrations are met. This places the model as a top choice when thinking of river water policy options.

\section{Conflicts of Interest}

The authors declare no conflicts of interest regarding the publication of this paper.

\section{References}

[1] Barth, F. (1998) Die EU-Wasserrahmenrichtlinie und ihreAuswirkungen auf die Wasserwirtschafl in BadenWthttemberg. Wasser and Boden, Boppard, 88, H. 9, 446-449.

[2] Sokolov, S. and Black, K.P. (1996) Modeling the Time Evolution of Water-Quality Parameters in a River: Yarra River, Australia. Journal of Hydrology, 178, 311-333. 
https://doi.org/10.1016/0022-1694(95)02797-1

[3] Cox, B.A. (2003) A Review of Currently Available In-Stream Water-Quality Models and Their Applicability for Simulating Dissolved Oxygen in Lowland Rivers. The Science of the Total Environment, 314-316, 335-377. https://doi.org/10.1016/S0048-9697(03)00063-9

[4] US EPA (1986) Quality Criteria for Water, Gold Book Quality Criteria. EPA 440/5-86-001, U.S. Environmental Protection Agency, Office of Water, Washington DC.

[5] Erlend, E. (2002) Dimensions of a River. Bagmati River, Kathmandu, Nepal, a Master Thesis, Institute for Geography, University of Bergen, Bergen.

[6] Taylor, G.D., Fletcher, T.D., Wong, T.H.F., Breen, P.F. and Duncan, H.P. (2005) Nitrogen Composition in Urban Runoff: Implications for Storm-Water Management. Water Research, 39, 1982-1989. https://doi.org/10.1016/j.watres.2005.03.022

[7] Campolo, M., Andreussi, P. and Soldati, A. (2002) Water Quality Control in the River Arno, Technical Note. Water Research, 36, 2673-2680.

https://doi.org/10.1016/S0043-1354(01)00483-3

[8] Herbay, J.P., Smeers, Y. and Tyteca, D. (1983) Water Quality Management with Time Varying River Flow and Discharger Control. Water Research, 19, 1481-1487. https://doi.org/10.1029/WR019i006p01481

[9] Hayes, D.F., Labadie, J.W., Sanders, T.G. and Brown, J.K. (1998) Enhancing Water Quality in Hydropower System Operations. Water Research, 34, 471-483.

https://doi.org/10.1029/97WR03038

[10] McIntyre, N.R. and Wheater, H.S. (2004) A Tool for Risk-Based Management of Surface Water Quality. Environmental Modeling \& Software, 19, 1131-1140. https://doi.org/10.1016/j.envsoft.2003.12.003

[11] Deksissa, T., Meirlaen, J., Ashton, P.J. and Vanrolleghem, P.A. (2004) Simplifying Dynamic River Water Quality Modeling: A Case Study of Inorganic Dynamics in the Crocodile River (South Africa). Water, Air, and Soil Pollution, 155, 303-320. https://doi.org/10.1023/B:WATE.0000026548.20608.a0

[12] Brown, L.C. and Barnwell Jr., T.O. (1987) The Enhanced Stream Water Quality Models QUAL2E and QUAL2EUNCAS: Documentation and User Manual. USEPA, Environmental Research Laboratory, Athens, 189, EPA/600/3-87/007.

[13] Park, S.S. and Lee, Y.S. (2002) A Water Quality Modeling Study of the Nakdong River Korea. Ecological Modeling, 152, 65-75. https://doi.org/10.1016/S0304-3800(01)00489-6

[14] Park, S.S. and Lee, Y.S. (1996) A Multiconstituent Moving Segment Model for the Water Quality Predictions in Steep and Shallow Streams. Ecological Modeling, 89, 121-131. https://doi.org/10.1016/0304-3800(95)00126-3

[15] Park, S.S. and Uchrin, C.G. (1990) Water Quality Modeling of the Lower South Branch of the Raritan River, New Jersey. Bulletin of N.J. Academy of Science, 35, 17-23.

[16] Park, S.S. and Uchrin, C.G. (1996) Waste Load Allocation for Macrophyte Growing Impoundment: A Combined Modeling Approach. Journal of Environmental Science and Health A, 31, 411-428. https://doi.org/10.1080/10934529609376365

[17] Ambrose, R.B., Wool, T.A., Connolly, J.P. and Shanz, R.W. (1987) WASP5, a Hydrodynamic and Water Quality Model. U.S. Environmental Protection Agency, Athens, EPA/600/3-87/039.

[18] Park, S.S. and Uchrin, C.G. (1997) A Stoichiometric Model for Water Quality Inte- 
ractions in Macrophyte Dominated Waterbodies. Ecological Modeling, 96, 165-174. https://doi.org/10.1016/S0304-3800(96)00064-6

[19] Chapra, S.C. and Pelletier, G.J. (2003) QUAL2K: A Modeling Framework for Simulating River and Stream Water Quality (Beta Version): Documentation and Users Manual. Civil and Environmental Engineering Dept., Tufts University, Medford.

[20] Pelletier, G.J. and Chapra, S.C. (2005) QUAL2Kw Theory and Documentation (Version 5.1), a Modeling Framework for Simulating River and Stream Water Quality. http://www.ecy.wa.gov/programs/eap/models

[21] Pelletier, G.J., Chapra, C.S. and Tao, H. (2005) QUAL2Kw-A Framework for Modeling Water Quality in Streams and Rivers Using a Genetic Algorithm for Calibration. Environmental Modeling \& Software, 21, 419-425. https://doi.org/10.1016/j.envsoft.2005.07.002

[22] APHA, AWWA and WPCF (1989) Standard Methods for the Examination of Water and Wastewater. 17th Edition, American Public Health Association (APHA), American Water Works Association (AWWA) and Water Pollution Control Federation (WPCF), Washington DC.

[23] Owens, M., Edwards, R.W. and Gibbs, J.W. (1964) Some Reaeration Studies in Streams. International Journal of Air and Water Pollution, 8, 469-486.

[24] Ghosh, N.C. and Mcbean, E.A. (1998) Water Quality Modeling of the Kali River, India. Water, Air, and Soil Pollution, 102, 91-103. https://doi.org/10.1023/A:1004912216834

[25] George, L.B., William, B.M., Donald, B.P., Carrie, L.C., James, R.P., Gretchen, L.R., Kay, M.J., Peter, W.H.C., Steven, A.G. and Charles, E.C. (1985) Rates, Constants, and Kinetic Formulations in Surface Water Quality Modeling. Second Edition, U.S. Environmental Protection Agency, EPA/600/3-85/040, Washington DC.

[26] US EPA (1985) Screening Procedure for Toxic and Conventional Pollutants in Surface and Ground Water. EPA/600/6-85/002a, U.S. Environmental Protection Agency, Athens. 